\title{
Pseudohyponatremia in a neuroblastoma patient with obstructive jaundice and review of literature
}

\author{
Marta Bassi ${ }^{1}$, Carla Manzitti ${ }^{2}$, Shana Montalto ${ }^{1}$, Serena Giglio ${ }^{1}$, Massimo Conte ${ }^{2}$, Fabio Facco ${ }^{3}$ and Loredana Amoroso $^{2 *}$ \\ ${ }^{1}$ Department of Pediatrics, IRCCS Istituto Giannina Gaslini, University of Genova, Genova, Italy \\ ${ }^{2}$ Department of Oncology, IRCCS Istituto Giannina Gaslini, Genova, Italy \\ ${ }^{3}$ Central Laboratory, IRCCS Istituto Giannina Gaslini, Genova, Italy
}

\begin{abstract}
Background: Pseudohyponatremia is uncommonly associated with severe hypercholesterolemia. Case presentation: We report a case of pseudohyponatremia in a pediatric patient with severe hypercholesterolemia caused by obstructive jaundice. A 20-month-old female was hospitalized following a diagnosis of abdominal neuroblastoma related to asymptomatic hyponatremia.
\end{abstract}

Results: This is the first pediatric report of falsely low sodium levels in a child with severe hypercholesterolemia caused by abdominal neuroblastoma mass-related obstructive jaundice. At presentation we observed asymptomatic hyponatremia (126 mmol/L; normal range: $135-145 \mathrm{mEq} / \mathrm{L})$, while she was later found to have $16.7 \mathrm{mg} / \mathrm{dl}$ total bilirubin and $870 \mathrm{mg} / \mathrm{dL}$ total serum cholesterol (normal range: $80-180 \mathrm{mg} / \mathrm{dL}$ ). Pseudohyponatremia was diagnosed and confirmed by direct potentiometric measurement of serum osmolality $(279 \mathrm{mOsm} / \mathrm{kg}$; normal range: $275-290 \mathrm{mOsm} / \mathrm{kg})$ and serum sodium $(135 \mathrm{mmol} / \mathrm{L})$, performed on a blood gas analyzer. It is unusual to observe an association of pseudohyponatremia with severe hypercholesterolemia.

Conclusion: We report that extreme hypercholesterolemia in cholestasis may actually be a rare cause of pseudohyponatremia. This underscores the need to carry out serum sodium evaluation with direct potentiometry when extreme hypercholesterolemia is present, and how important it is to achieve a differential diagnosis between pseudohyponatremia and hyponatremia prior to starting treatment, especially in the pediatric setting.

\section{Introduction}

Hyponatremia, defined as serum sodium concentration $<135$ $\mathrm{mEq} / \mathrm{L}$, is a common electrolyte disorder in children which affects between 15 and $30 \%$ of hospitalized pediatric and adult subjects [1-3].

On the basis of the underlying etiology, classification of hyponatremia may be:

1 Hypotonic hyponatremia; this is connected to reduced serum osmolality $(<275 \mathrm{mmol} / \mathrm{l})$ in the presence of increased water retention involving heart failure, nephrotic syndrome, renal failure, etc.

2 Hypertonic hyponatremia; serum osmolality increases to $>295$ $\mathrm{mmol} / \mathrm{l}$ when high osmolar solutes including glucose, mannitol, intravenous radiocontrast agents, etc. are present.

3 Isotonic hyponatremia; pseudohyponatremia should be taken into consideration.

Pseudohyponatremia is characterized by a spurious, low serum sodium concentration against a background of normal serum osmolality $[4,5]$. In cases of pseudohyponatremia, hyponatremia is related to the presence of hypertriglyceridemia or hyperproteinemia and, in rare cases, to hypercholesterolemia. The above-mentioned conditions are connected to a decrease in both plasma water fraction and in measured sodium concentration [6].

Direct and indirect ion selective electrodes (ISEs) are two methods used in order to measure the electrolytes such as sodium. In clinical practice, sodium concentration in plasma water, measured by direct ISE, is important to consider as it is responsible of water movements between the liquid compartments. Knowing the difference between the two methods is important. The increase and the decrease in plasma water volume are the conditions that distort the results of the indirect ISE because, this method, after a dilution step, does not take into account the real percentage of plasma water of the patient in the determination of the concentrations. In direct ISE, the sample is not diluted, and the results are correct even if the volume of plasma water is modified as occurs with hyperlipemic and hyperproteinemic samples.

Hence, false low sodium levels may be observed when the indirect method is used. In these cases, using the direct method may prevent this issue [7]. Differentiating pseudohyponatremia from true hyponatremia is crucial since a misunderstanding regarding the discrepancy between the measured and physiological sodium concentrations may result in grave errors in managing the pediatric patient. Aggressive treatment of misdiagnosed pseudohyponatremia may result in greater morbidity and mortality.

${ }^{\star}$ Correspondence to: Loredana Amoroso, Department of Oncology, IRCCS Istituto Giannina Gaslini, Genova, Italy, Tel: +39 01056363582; E-mail: loredanaamoroso@gaslini.org

Key words: pseudohyponatremia; pediatric oncology; cholestasis, hypercholesterolemia; neuroblastoma

Received: April 13, 2021; Accepted: April 20, 2021; Published: April 27, 2021 


\section{Case presentation}

We admitted a 20-month-old girl to our institution for further investigation after she had been diagnosed with abdominal neuroblastoma and treated with one cycle of chemotherapy in her home country of Albania. The child had a history of jaundice, extremely dark urine and pale stools, and at presentation was severely jaundiced. However, there were no reports of pruritus, nausea, vomiting, bruising or bleeding, and at admission she had no fever, her pulse rate was 120 bpm, respiratory rate was $28 \mathrm{bpm}$ and her blood pressure was 100/80 $\mathrm{mmHg}$. Upon examination we observed jaundice, icteric sclerae, and a tender and distended abdomen, although neither hepatomegaly nor edema in the lower extremities was seen.

A CT scan confirmed the solid abdominal mass that had been seen at abdominal ultrasound as a median retroperitoneal solid mass $(80 \times 60 \times 40 \mathrm{~mm})$ incorporating the celiac trunk, superior mesenteric artery, and kidney vessels. The mass had found its way into the hepatic hilum resulting in extrinsic compression of the common bile duct, gallbladder hydrops, ectasia of the intrahepatic biliary tract and dislocation of the portal vein. The biopsy that had been carried out in Albania was reviewed and we confirmed the diagnosis of undifferentiated MYCN-amplified neuroblastoma.

Testing at admission revealed the following: blood hemoglobin concentration $10.8 \mathrm{~g} / \mathrm{dL}$, white blood cells $11.10 \times 10 . \mathrm{e} 3 / \mu \mathrm{l}$, neutrophils $9.39 \times 10 . \mathrm{e} 3 / \mu \mathrm{l}$, lactate dehydrogenase $834 \mathrm{U} / \mathrm{L}$, and activated protein C $1.76 \mathrm{mg} / \mathrm{dL}$; a severe cholestatic picture with elevated total and direct bilirubin levels (16.7 and $15.24 \mathrm{mg} / \mathrm{dL}$, respectively), aspartate aminotransferase (AST, $191 \mathrm{U} / \mathrm{L}$ ), gamma-glutamyl transferase (GGT, $1142 \mathrm{U} / \mathrm{L}$ ), alkaline aminotransferase (ALT, $332 \mathrm{U} / \mathrm{L}$ ); urinary catecholamine levels were pathologic (homovanillic acid and vanillymandelic acid 216 and $43 \mu \mathrm{mol} / \mathrm{mmol}$ creat, respectively).

Based on the European protocol, we began chemotherapy with Carboplatin and Etoposide, and at the same time molecular tests were run.

Following two cycles of chemotherapy, 123-I-meta-iodo-benzylguanidine (mIBG) scintigraphy was carried out which revealed focal enhancement at the tumor site that was compatible with the histological diagnosis. MYCN amplification was confirmed by molecular testing, thus, the tumor was classified as high-risk and the SIOPEN protocol NB-AR-01 was adopted.

Laboratory tests, performed after 2 cycles of chemotherapy, showed the following serum levels; sodium $126 \mathrm{mEq} / \mathrm{l}$, potassium 4.2 $\mathrm{mEq} / \mathrm{l}$, chloride $91 \mathrm{mEq} / \mathrm{l}$, and serum osmolality $279 \mathrm{mOsm} / \mathrm{kg}$, while total serum cholesterol was $870 \mathrm{mg} / \mathrm{dL}$ (normal range: $80-180 \mathrm{mg}$ / $\mathrm{dL}$ ) and triglycerides were $168 \mathrm{mg} / \mathrm{dL}$ (normal range: 64 to $122 \mathrm{mg} /$ dL). Supplementation with omega-3 fatty acids was started to reduce triglyceride levels.

We first believed the child had hypovolemic hyponatremia and therefore she was administered intravenous normal saline. However, since a repeat sodium evaluation showed no changes, intravenous sodium supplementation as high as $10 \mathrm{mEq} / \mathrm{kg}$ over 24 hours was given. No improvement in her sodium level was observed, hence pseudohyponatremia was taken into consideration.

Measuring serum osmolality (279 mOsm/kg; normal range: 275-290 $\mathrm{mOsm} / \mathrm{kg})$ and serum sodium $(135 \mathrm{mmol} / \mathrm{L})$ by direct potentiometric measurement, performed on blood gas analyzer, allowed us to confirm pseudohyponatremia. No lipoprotein electrophoresis was carried out.

Either direct or indirect ion-selective electrode methods may be adopted to evaluate sodium concentration. Indirect ISE involves diluting the sample prior to analysis and measuring the electrolyte concentration in the serum based on the assumption that plasma is made up of $93 \%$ water. In the presence of hyperlipidemia and hypercholesterolemia, the plasma water fraction decreases, and thus indirect ISE testing will result in falsely low sodium levels. On the other hand, no dilution is needed in direct ISE testing, and so sodium is measured directly regardless of plasma water fraction, and therefore any changes in plasma percentage concentration will not affect the results. Repeat blood tests utilizing both the direct and indirect methods were carried out at the same time to evaluate electrolyte levels, and the results are shown in Table 1.

\section{Discussion}

The low sodium concentration we observed in this patient is considered a sign of pseudohyponatremia attributable to

Table 1. Comparison between direct and indirect methods

\begin{tabular}{|c|c|c|c|c|c|c|}
\hline & \multicolumn{3}{|c|}{$\begin{array}{l}\text { Indirect ion-selective } \\
\text { electrode method }\end{array}$} & \multicolumn{3}{|c|}{ Blood gas analyzer (direct method) } \\
\hline & \multicolumn{3}{|c|}{ Supplementation of sodium (mEq/kg in $24 \mathrm{~h}$ ( i.v.) } & \multicolumn{3}{|c|}{ Supplementation of sodium (mEq/kg in 24 h ( i.v.) } \\
\hline & $10 \mathrm{mEq} / \mathrm{Kg}$ & $7 \mathrm{mEq} / \mathrm{Kg}$ & $6 \mathrm{mEq} / \mathrm{Kg}$ & $10 \mathrm{mEq} / \mathrm{Kg}$ & $7 \mathrm{mEq} / \mathrm{Kg}$ & $6 \mathrm{mEq} / \mathrm{Kg}$ \\
\hline & Day1 & Day2 & Day3 & Day1 & Day2 & Day3 \\
\hline \begin{tabular}{|l|} 
Sodium \\
$\mathrm{mEq} / \mathrm{I}$
\end{tabular} & 126 & 126 & 129 & 135 & 134 & 138 \\
\hline $\begin{array}{l}\text { Potassium } \\
\mathrm{mEq} / \mathrm{l}\end{array}$ & 4.1 & 4 & 3.9 & 4.5 & 4.2 & 3.9 \\
\hline $\begin{array}{l}\text { Chloride } \\
\mathrm{mEq} / \mathrm{l}\end{array}$ & 94 & 92 & 98 & 101 & 101 & 105 \\
\hline $\begin{array}{l}\text { Bilirubin (total) } \\
\mathrm{mg} / \mathrm{dl}\end{array}$ & 17 & 15 & 14 & 16 & 14 & 14 \\
\hline $\begin{array}{l}\text { Bilirubin (direct) } \\
\mathrm{mg} / \mathrm{dl}\end{array}$ & 15 & 13 & 13 & nd & nd & nd \\
\hline $\begin{array}{l}\text { Plasma Osmolality } \\
\text { mOsm/Kg }\end{array}$ & 257 & 253 & nd & 279 & 273 & 279 \\
\hline $\begin{array}{l}\text { Triglycerides } \\
\text { mg/dl }\end{array}$ & 146 & 145 & 223 & nd & nd & nd \\
\hline $\begin{array}{l}\text { Cholesterol (total) } \\
\mathrm{mg} / \mathrm{dl}\end{array}$ & 791 & 702 & 635 & nd & nd & nd \\
\hline
\end{tabular}


hypercholesterolemia. There are two ways to measure electrolytes in plasma, both of which use an ISE. The first method measures electrolyte activity in plasma with no dilution. It involves direct potentiometry and is used in point-of-care blood gas analyzers. The second method is indirect ISE, which is used in routine chemistry analyses in central laboratories, and it includes a pre-analysis serum or plasma dilution step $[8,9]$.

Indirect ion-selective electrode potentiometry, which is used in our laboratory, is among the methods of electrolyte analysis that are based on the assumption that plasma water content does not change and that $93 \%$ of plasma is water. In the presence of hyperlipidemia or hyperproteinemia, the plasma water fraction decreases, and thus indirect ISE will show falsely low sodium levels because the decreased plasma water fraction is not taken into consideration.

The direct method measures sodium concentration directly using undiluted samples, regardless of serum plasma concentration and consequently the result is not affected by changes in plasma percentage concentration.

The exact reason hypercholesterolemia occurs with cholestasis is still not known, however there may be several contributing factors. Unesterified cholesterol, that is mainly transported as lipoprotein $\mathrm{X}$ (LpX), is the predominant cause of hypercholesterolemia. Hepatic lipase, lipoprotein lipase and cholesterol acyltransferase (LCAT) deficiencies may be observed in cholestasis. While LpX does not inhibit hydroxymethylglutaryl coenzyme A (HMG-CoA) reductase (a ratelimiting enzyme in cholesterol synthesis), it does not interfere with the ability of LDL to lower HMG-CoA reductase activity either $[10,11]$.

Indeed, cholestatic liver disease shows both enhanced HMGCoA reductase activity (suggesting that cholesterol synthesis has been stimulated) and depressed cyp7 activity (suggesting that the conversion of cholesterol into bile is not so efficient) [12].

In cholestasis, bile lipoprotein flows into the plasma pool and binds to albumin, thus forming Lp-X. Changes in 11b-hydroxysteroid dehydrogenase (which itself contributes to electrolyte abnormalities that are similar to those observed in a mineralocorticoid excess state) are also linked to cholestasis.

Low plasma sodium levels in the context of normal osmolarity is defined as pseudohyponatremia, and it is a measurement artifact that is observed in case of an increase in the non-aqueous part of plasma.To date, only 13 cases of hypercholesterolemia-associated pseudohyponatremia have been reported, and all but one involved adults, the lone exception being a 14-year- old child, Table 2 [13-25].

All the reported patients had cholestasis and can be subdivided as follows; 4 had graft-versus-host disease following bone marrow transplantation, 3 had primary biliary cirrhosis, 2 cases were druginduced, 2 had obstructive jaundice, 1 had hepatitis $C$, and 1 had pancreatic cancer. Among these cases, the lowest reported total serum cholesterol level that eventually led to pseudohyponatremia was 977 $\mathrm{mg} / \mathrm{dL}$ (associated serum sodium: $129 \mathrm{mmol} / \mathrm{L}$ ), while the highest value was $4091 \mathrm{mg} / \mathrm{dL}$ (associated serum sodium:101 mmol/L).

We may assume that hypercholesterolemia, with or without hypertriglyceridemia, can cause pseudohyponatremia. Our reliance on electrolytes from samples obtained from indirect ISE analysis as the sole determinant of sodium concentrations predisposed our team to treat electrolyte alterations that were, in reality, factitious. Once we compared the results obtained from direct ISE analysis, we were able to classify our results as solely a laboratory abnormality.

Our experience with this patient highlights the need to take pseudohyponatremia into consideration prior to starting treatment for suspected hyponatremia which could result in complications, especially in the pediatric setting. All hyponatremic patients with cholestasis should undergo serum osmolality evaluation, and in case of normal serum osmolality, direct potentiometry should be adopted to measure sodium levels.

Therefore, it is vital to be aware of the laboratory practices that are standard at one's own institution to properly interpret results. In such patients, we urge clinicians to compare results measured in indirect ISE

Table 2. Literature review of cases of pseudohyponatremia associated with hypercholesterolemia

\begin{tabular}{|c|c|c|c|c|}
\hline Age, sex & Underlying diagnosis & $\begin{array}{c}\text { Sodium } \\
\text { Indirect method }\end{array}$ & $\begin{array}{c}\text { Sodium } \\
\text { Direct method }\end{array}$ & Total cholesterol \\
\hline $1, \mathrm{~F}$ & neuroblastoma & $126 \mathrm{mEq} / 1$ & $135 \mathrm{mEq} / 1$ & $791 \mathrm{mg} / \mathrm{dl}$ \\
\hline $14, \mathrm{M}$ & Acute myeloid leukemia & $123 \mathrm{mmol} / \mathrm{l}$ & nd & $1,667 \mathrm{mg} / \mathrm{dl}$ \\
\hline $27, \mathrm{M}$ & Primary biliary cirrhosis & $116 \mathrm{mmol} / \mathrm{l}$ & $132 \mathrm{mmol} / 1$ & $\begin{array}{c}47 \mathrm{mmol} / 1 \\
1,830 \mathrm{mg} / \mathrm{dl}\end{array}$ \\
\hline $29, \mathrm{~F}$ & Obstructive liver disease & $116 \mathrm{mmol} / 1$ & nd & $\begin{array}{c}72 \mathrm{mmol} / \mathrm{l} \\
2,815 \mathrm{mg} / \mathrm{dl}\end{array}$ \\
\hline $36, \mathrm{M}$ & Quetiapine-associated cholestasis & $119 \mathrm{mmol} / \mathrm{l}$ & nd & $\begin{array}{l}219 \mathrm{mmol} / 1 \\
1,691 \mathrm{mg} / \mathrm{dl}\end{array}$ \\
\hline $37, \mathrm{M}$ & Chronic myelogenous leukemia & $129 \mathrm{mmol} / \mathrm{l}$ & $135 \mathrm{mmol} / 1$ & $\begin{array}{l}25 \mathrm{mmol} / 1 \\
977 \mathrm{mg} / \mathrm{dl}\end{array}$ \\
\hline $40, \mathrm{M}$ & $\begin{array}{l}\text { Lymphoplasmacytic sclerosing } \\
\text { cholangitis }\end{array}$ & $121 \mathrm{mEq} / 1$ & $138 \mathrm{mEq} / 1$ & $2,109 \mathrm{mg} / \mathrm{dl}$ \\
\hline $41, \mathrm{~F}$ & Acute Hepatitis C & $120 \mathrm{mmol} / 1$ & nd & $2,621 \mathrm{mg} / \mathrm{dl}$ \\
\hline $43, \mathrm{~F}$ & Primary biliary cirrhosis & $121 \mathrm{mmol} / 1$ & $141 \mathrm{mmol} / 1$ & $2,415 \mathrm{mg} / \mathrm{dl}$ \\
\hline $55, \mathrm{~F}$ & Acute lymphoblastic leukemia & $101 \mathrm{mmol} / 1$ & nd & $4,091 \mathrm{mg} / \mathrm{dl}$ \\
\hline $61, \mathrm{~F}$ & Pancreatic cancer & $108 \mathrm{mmol} / 1$ & nd & $1,713 \mathrm{mg} / \mathrm{dl}$ \\
\hline $62, \mathrm{~F}$ & Primary biliary cirrhosis & $115 \mathrm{mmol} / \mathrm{l}$ & $134 \mathrm{mmol} / 1$ & $\begin{array}{c}78 \mathrm{mmol} / 1 \\
3,011 \mathrm{mg} / \mathrm{dl}\end{array}$ \\
\hline $64, \mathrm{~F}$ & Acute myelogenous leukemia & $124 \mathrm{mmol} / 1$ & $135 \mathrm{mmol} / 1$ & $\begin{array}{c}47 \mathrm{mmol} / \mathrm{l} \\
1,836 \mathrm{mg} / \mathrm{dl}\end{array}$ \\
\hline $69, \mathrm{M}$ & Drug induced cholestatic hepatitis & $119 \mathrm{mmol} / \mathrm{l}$ & $132 \mathrm{mmol} / 1$ & $1,340 \mathrm{mg} / \mathrm{dl}$ \\
\hline
\end{tabular}


with results obtained in direct ISE using blood gas analyzers. In our opinion, it is reasonable to simply observe pseudhyponatremia since the patient actually has normal serum sodium while working to correct the underlying causes of high triglycerides and/or high cholesterol.

\section{Conclusion}

Careful work-up should be performed to distinguish pseudohyponatremia from hyponatremia in pediatric patients presenting hypercholesterolemia, hypertriglyceridemia, or hyperproteinemia in order to prevent mismanagement that could eventually result in increased morbidity and mortality.

\section{References}

1. Feld LG, Neuspiel DR, Foster BA, Leu MG, Garber MD, et al. (2018) Subcommittee on fluid and electrolyte therapy. Clinical practice guideline: Maintenance intravenous fluids in children. Pediatrics 142: e20183083.

2. Carandang F, Anglemyer A, Longhurst CA, Krishnan G, Alexander SR, et al. (2013) Association between maintenance fluid tonicity and hospital-acquired hyponatremia. $J$ Pediatr 163:1646-1651. [Crossref]

3. Upadhyay A, Jaber BL, Madias NE (2006) Incidence and prevalence of hyponatremia. Am J Med 119: S30-S35.

4. Zieg J (2017) Pathophysiology of hyponatremia in children. Front Pediatr 5: 213. [Crossref]

5. Wald R, Jaber BL, Price LL, Upadhyay A, Madias NE (2010) Impact of hospitalassociated hyponatremia on selected outcomes. Arch Intern Med 170: 294-302. [Crossref]

6. Kim GH (2006) Pseudohyponatremia: Does it matter in current clinical practice? Electrolyte Blood Press 4: 77-82. [Crossref]

7. Rondon-Berrios H, Agaba EI, Tzamaloukas AH, Hyponatremia: Pathophysiology, classification, manifestations and management. Int Urol Nephrol 46: 2153-2165. [Crossref]

8. Fortgens P, Pillay TS (2011) Pseudohyponatremia revisited: A modern-day pitfall. Arch Pathol Lab Med 135: 516-519. [Crossref]

9. Schindler EI, Brown SM, Scott MG (2018) Electrolytes and blood gases, in: N. Rifai, A.R. Horvath, C.T. Wittwer (Eds.), Tietz Textbook of Clinical Chemistry and Molecular Diagnostics, 6 ed., Elsevier, St. Louis, Missouri, USA. pp. 604-625.

10. Baldo-Enzi G, Baiocchi MR, Grotto M, Floreani AR, Zagolin M, et al. (1988) Lipoprotein pattern and plasma lipoprotein lipase activities in patients with primary biliary cirrhosis. Relationship with increase of HDL2 fraction in Lp-X-positive and Lp-X-negative subjects. Dig Dis Sci 33: 1201-1207. [Crossref]
11. Edwards CM, Otal MP, Stacpoole PW (1993) Lipoprotein-X fails to inhibit hydroxymethylglutaryl coenzyme A reductase in HepG2 cells. Metabolism 42: 807813. [Crossref]

12. Chisholm JW, Nation P, Dolphin PJ, Agellon LB (1999) High plasma cholesterol in drug-induced cholestasis is associated with enhanced hepatic cholesterol synthesis. Am J Physiol 276: G1165-G1173. [Crossref]

13. Sivakumar T, Chaidarun S, Lee HK, Cervinski M, Comi R (2011) Multiple lipoprotein and electrolyte laboratory artifacts caused by lipoprotein $\mathrm{X}$ in obstructive biliary cholestasis secondary to pancreatic cancer. J Clin Lipidol 5: 324-328. [Crossref]

14. Coakley JC, Vervaart PP, McKay MR (1986) Factitious hyponatremia in a patient with cholestatic jaundice following bone marrow transplantation. Pathology 18:158-159. [Crossref]

15. Ravella S, Lefavour GS, Carayannopoulos MO, Parikh A (2015) Hyponatremia in a patient with obstructive jaundice. Kidney Int 88: 921-922.

16. El Hage L, Reineks E, Nasr C (2018) Pseudohyponatremia in the setting of hypercholesterolemia. AACE Clin Case Rep 5: e172-e174. [Crossref]

17. Hussain I, Ahmad Z, Garg A (2015) Extreme hypercholesterolemia presenting with pseudohyponatremia - a case report and review of the literature. J Clin Lipidol 9: 260264. [Crossref]

18. Kittisupamongkol W (2008) Pseudohyponatremia in elderly patients. QJM 101: 828.

19. Vo H, Gosmanov AR, Garcia-Rosell M, Wall BM (2013) Pseudohyponatremia in acute liver disease. Am J Med Sci 345: 62-64. [Crossref]

20. Song L, Hanna RM, Nguyen MK, Kurtz I, Wilson J (2018) A novel case of pseudohyponatremia caused by hypercholesterolemia. Kidney Int Rep 4: 491-493. [Crossref]

21. Inamoto Y, Teramoto T, Shirai K, Tsukamoto H, Sanda T, et al. (2005) Severe hypercholesterolemia associated with decreased hepatic triglyceride lipase activity and pseudohyponatremia in patients after allogeneic stem cell transplantation. Int $J$ Hematol 82: 362-366. [Crossref]

22. Turchin A, Wiebe DA, Seely EW, Graham T, Longo W, et al. (2005) Severe hypercholesterolemia mediated by lipoprotein $\mathrm{X}$ in patients with chronic graft-versushost disease of the liver. Bone Marrow Transplant 35: 85-89.

23. le Riche M, Burgess LJ, Marais AD (2005) Pseudohyponatraemia in a patient with obstructive jaundice. Clin Chim Acta 366: 357-360. [Crossref]

24. Hickman PE, Dwyer KP, Masarei JR (1989) Pseudohyponatraemia, hypercholesterolaemia, and primary biliary cirrhosis. J Clin Pathol 42:167-171. [Crossref]

25. Ko GT, Yeung VT, Chow CC, Mak TW, Cockram CS (1997) Pseudohyponatraemia secondary to hypercholesterolaemia. Ann Clin Biochem 34: 324-325. [Crossref]

Copyright: (C2021 Bassi M. This is an open-access article distributed under the terms of the Creative Commons Attribution License, which permits unrestricted use, distribution, and reproduction in any medium, provided the original author and source are credited. 